\title{
大学生の仕事に関する価値観、就業自己イメージと両親のワー ク・エンゲイジメントのイメージの関連
}

\author{
設楽紗英子 1 - 新井邦二郎 ${ }^{1}$ \\ ( 1 筑波大学大学院人間総合科学研究科) \\ キーワード: ワーク・エンゲイジメント、仕事に関する価值観、就業自己イメージ
}

\begin{abstract}
Work values, self-image after attaining an occupation and images of parents' work engagement among university students
\end{abstract}
Saeko SHITARA ${ }^{1}$, Kunijiro Arai

('Graduate School of Comprehensive Human Sciences, Univ. of Tsukuba)

Key words: work engagement, work values, self-image after attaining an occupation

\section{【目的】}

一般的に、子どもは親を見て育つと言われる。親は子ども にとって最も身近な職業人であり、親の働く姿は子どもにと って、仕事に関する価值観や、働いている自分に対する将来 の見通しに対して、何らかの影響を持つものであると考えら れる。そして、社会人としてのキャリア選択の局面に立たさ れ、人生の重要なトランジションの最中にあって、どのよう に仕事に関する価值観や、働いている自分のイメージを持つ かは、大学生にとって重要な働きを持つものと考えられる。 そこで本研究では、大学生がどのように両親のワーク・エン ゲイジメントのイメージを持っているかということと、彼ら の仕事に関する価值観、および就業自己イメージとの関連を 検討することを目的とする。

\section{【方法 】}

対象者 大学生 302 名（男子 183 名、女子 119 名、平均 19,8 歳 $(S D=.99))$ であった。

調查時期 2009 年 4 月

調査内容 (1)仕事に関する価值観 仕事に関する価值観尺 度（森永、1993；1995）を用いた。23 項目 5 件法であり、回 答ラベルは“重要でない（1）～重要である（5)”であった。 (2)就業自己イメージ 清水・下斗米・風間（2003；2005）で 作成された就業自己イメージ尺度の各下位尺度から因子負荷 量の大きい上位 5 項目を選択した。ただし、下位尺度が 5 項 目に満たない場合は全ての項目を用いた。43 項目、7 件法で あり、回答ラベルは“きわめてそう思う（1）〜きわめてそう 思わない（7）”であった。

(3)両親のワーク・エンゲイジメントのイメージ UWES-J ( Utrecht Work Engagement Scale: Schaufeli, Salanova, González-Romá, \& Bakker, 2002; 島津・小杉・鈴木・梨和・加 登・平賀・入交・北岡（2007））を用い、父親と母親それぞれ について、仕事への取り組み方のイメージを尋ねた。9 項目、 7 件法で、回答ラベルは“全くない（0）〜いつもある（6）” であった。

\section{【結果と考察】}

（1）各尺度の因子構造の検討 仕事に関する価值観尺度 仕 事に関する価值観を検討するため、男女別に因子分析を行っ た（主因子法、バリマックス回転）。その結果、男子では 4 因子 (活性的な取り組み、労働条件、社会的意義、職場条件、 $\alpha=.75 \sim .82$ )、女子では 3 因子(職場条件、働く意義、社 会的貢献、 $\alpha=.75 \sim .83)$ が抽出された。

就業自己イメージ尺度 就業自己イメージを検討するた め、男女別に因子分析を行った（主因子法、バリマックス回 転)。その結果、男子では 5 因子（主体性、立場の気楽さ、地 位志向性、上下関係への気遣い、競争的関係性、 $\alpha=.62$ 〜.90)、女子では 4 因子（主体性、立場の優位性、立場の気
楽さ、立場への配慮、 $\alpha=.61 \sim .90 ）$ が抽出された。

UWES-J 1 因子構造を確認するため、フルタイム、もし くはパート/アルバイトで働いている父親と母親の両方につ いて回答されたもの（男子 118 名、女子 81 名）を用いて主成 分分析を行ったところ、父親と母親の両方で十分な值が得ら れた。 $\alpha$ 係数は.94〜.95 であった。

（2）各下位尺度間の相関 両親のワーク・エンゲイジメント のイメージと他の下位尺度との間で相関係数を男女別に求め、 その結果を Table 1, 2 に示した。

\begin{tabular}{|c|c|c|c|}
\hline & & $\begin{array}{l}\text { 父親のワーク・エンゲ } \\
\text { イジメントのイメージ }\end{array}$ & $\begin{array}{l}\text { 母親のワーク・エンゲ } \\
\text { イジメントのイメージ }\end{array}$ \\
\hline \multirow{4}{*}{$\begin{array}{l}\text { 仕事に } \\
\text { 関する } \\
\text { 価値観 }\end{array}$} & 活性的な取り組み & $.20^{*}$ & $.23^{*}$ \\
\hline & 労働条件 & $.29^{* *}$ & .16 \\
\hline & 社会的意義 & $.24^{* *}$ & $.43^{* *}$ \\
\hline & 職場条件 & .03 & .14 \\
\hline & 主体性 & -.15 & $-.27^{* *}$ \\
\hline 就業 & 立場の気楽さ & -.02 & .02 \\
\hline 自己 & 地位志向性 & $-.22 *$ & $-.43^{* *}$ \\
\hline イメージ & 上下関係への気遣い & .01 & .10 \\
\hline & 競争的関係性 & $-.19^{*}$ & -.11 \\
\hline & $\begin{array}{l}\text { エシゲイジメシ } \\
\text { トのイメージ }\end{array}$ & & $.55^{* *}$ \\
\hline
\end{tabular}

Table 2. 下位尺度間の相関係数(女子)

\begin{tabular}{|c|c|c|c|}
\hline & & $\begin{array}{l}\text { 父親のワーク・エンゲ } \\
\text { イジメントのイメージ }\end{array}$ & $\begin{array}{c}\text { 母親のワーク・エンゲ } \\
\text { イジメントのイメージ }\end{array}$ \\
\hline \multirow{4}{*}{$\begin{array}{c}\text { 仕事に } \\
\text { 関する } \\
\text { 価値観 }\end{array}$} & 職場条件 & -.14 & -.12 \\
\hline & 働く意義 & .07 & -.01 \\
\hline & 社会的貢献 & -01 & .08 \\
\hline & 主体性 & $-30^{* *}$ & -.09 \\
\hline \multirow{3}{*}{$\begin{array}{l}\text { 就業自己 } \\
\text { イメージ }\end{array}$} & 立場の優位性 & -.13 & -.03 \\
\hline & 立場の気楽さ & -.18 & -.08 \\
\hline & 立場への配慮 & .00 & .10 \\
\hline \multicolumn{2}{|c|}{ 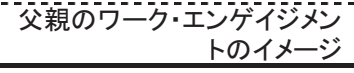 } & & $.24^{*}$ \\
\hline
\end{tabular}

結果より、両親のワーク・エンゲイジメントのイメージが 高いほど、男子において、活性的な取り組み、労働条件、社 会的意義などの価值観は高く、また、主体性、地位志向性、 競争的関係性のある自己のイメージは持ちにくくなること、 女子においても、主体性のある自己のイメージが低いことが 示された。このことから、特に男子において、両親の高いワ ーク・エンゲイジメントのイメージを持っているほど、働く ことに対する前向きな価值観を持つものの、逆に、将来働い ている自己に関しては、活き活きと積極的に働いていること をイメージしづらいようである。両親のポジティブに仕事に 取り組んでいる姿は、大学生にとってはポジティブな自己の イメージに抑制的に関与する可能性が示唆された。 